\title{
CULTURAL DEVELOPMENT: THE ARCHAEOLOGY OF KALIMANTAN TENGAH AND KALIMANTAN SELATAN
}

\author{
Vida Pervaya Rusianti Kusmartono* \\ Balai Arkeologi Banjarmasin, Jalan Gotong Royong II, RT 03/06, Banjarbaru 70711, Kalimantan Selatan; \\ Telepon (0511) 4781716; Facsimile (0511) 4781716
}

Artikel masuk pada 14 Februari 2012

Artikel selesai disunting pada 23 September 2012

\begin{abstract}
Abstrak. PERKEMBANGAN KEBUDAYAAN: ARKEOLOGI KALIMANTAN TENGAH DAN KALIMANTAN SELATAN. Selama 1993-2010, lebih dari tujuh puluh lima situs arkeologi di Provinsi Kalimantan Tengah dan Provinsi Kalimantan Selatan telah diteliti. Bukti-bukti arkeologi memberikan informasi penting tentang okupasi prasejarah, diaspora Austronesia dan tradisi penguburan, perkembangan kebudayaan India dan Cina, daerah aliran sungai dan pemukiman rawa, arsitektur Islam dan kolonial, perencanaan kota dan pemakaman, sistem benteng kolonial, perdagangan keramik, tradisi pembuatan tembikar dan logam, serta arkeologi bawah air. Namun demikian, karakteristik arkeologis masing-masing daerah tersebut menunjukkan kekhasan; Arkeologi Kalimantan Tengah menyajikan informasi tentang kontinuitas tradisi pemakaman prasejarah, sedangkan Arkeologi Kalimantan Selatan berkaitan dengan perkembangan kebudayaan Islam di bawah hegemoni Kesultanan Banjar dan okupasi Belanda.
\end{abstract}

Kata kunci: tradisi alat batu, kapal karam, tradisi pemakaman, Lawangan, Maanyan, Ngaju, Austromelanesid, benteng, Kesultanan Banjar, candi, masjid, tembikar, pengerjaan logam, toponimi

\begin{abstract}
During 1993-2010, over 75 archaeological sites in the Provinces of Kalimantan Tengah and Kalimantan Selatan have been extensively investigated. The archaeological evidences provide significant information on prehistoric occupation, Austronesia Diasporas and burial tradition, development of Indic and Chinese culture, river catchment and swamp settlement, Islamic and colonial architecture, urban planning and cemetery, colonial fortification system, ceramic trade, pottery and metalworking tradition and underwater archaeology. Nevertheless, archaeological characteristics between the two regions indicate distinctiveness; Kalimantan Tengah present more information on the continued prehistoric mortuary tradition, whereas Kalimantan Selatan relates to the development of Islamic culture under the hegemony of the Sultanate of Banjar and Dutch occupation.
\end{abstract}

Keywords: stone tool traditions, shipwreck, mortuary traditions, Lawangan, Maanyan, Ngaju, Austromelanesid, fortress, Sultanate of Banjar, candi, mosque, pottery, metalworking, toponymy

* $\quad$ presented at the First International Seminar "Bornean Archaeology: The Past, Present and Future Prospects", held by the Sarawak Museum Department in collaboration with the Department of National Heritage, the Ministry of Tourism and Heritage Sarawak and Malaysia Archaeology Association in Miri during 27-31 October 2010

** Penulis adalah Peneliti Madya pada Balai Arkeologi Banjarmasin, email: vkusmartono@yahoo.com 


\section{A. Introduction}

Kalimantan ${ }^{1}$ is the largest island in the Southeast Asian Archipelago. Administratively, $21.03 \%$ of the total width of the island, which is known as Borneo, is under the government of Malaysia and Brunei Darussalam. And, the remainder is within the authority of the Republic of Indonesia, which consists of four provinces i.e. Kalimantan Selatan, Kalimantan Tengah, Kalimantan Timur, and Kalimantan Barat. Before 1993, archaeological research in Kalimantan was scarce and only a number of sites have been introduced to the public such as Awangbangkal (Kalimantan Selatan), Muara Kaman (Kalimantan Timur), Kotawaringin Lama (Kalimantan Tengah) and Batu Pait (Kalimantan Barat). And, since the Centre for Archaeology (for Kalimantan) was established in Banjarmasin in July 1993, a large number of archaeological researches have been carried out extensively in the four provinces and present abundant data which provide significant information on cultural development that occurred in Kalimantan in the past.

Among the four provinces, Kalimantan Tengah and Kalimantan Selatan (Figure 1) has a shared-regional-establishment background ${ }^{2}$ (Rusan 2005, 120-135) and show common physiography of flat coastal lowland, swampy basin, highland and mountain covered with equatorial forest and ferns, and sliced by a large number of natural rivers and waterways. Due to the common physiographical environment, it is inevitable to discuss and refer both regions as southern Kalimantan. More than six $^{3}$ major archaeological research themes have been carried out in over 75 sites and present diverse archaeological information among others on prehistoric occupation, Austronesia diasporas and burial tradition, development of Indic and Chinese culture, river catchment and swamp settlement, Islamic and colonial architecture, urban planning and cemetery, colonial fortification system, ceramic trade, pottery and metalworking tradition and underwater archaeology. Nevertheless, the characteristic of cultural development in Kalimantan Tengah and Kalimantan Selatan indicate distinctiveness.

By examining archaeological reports and topographic maps, and carrying out field observations and literature studies, I will discuss leading archaeological discoveries in Kalimantan Tengah and Kalimantan Selatan;

1743,330 square kilometer in width; Treacher (MBRAS 1889) assumed the original name of Kalimantan was Sago Island, because sago grow very well in this island; moreover, the indigenous name of sago is lamantah or sago mentah (raw sago). On the other hand, Muljana (2006:88) asserts that Kalimantan was a Sanskrit loan word, Kalamanthana, which means island that burns; (kal[a] is season or time; and manthan[a] is to burn). Since the vocal [a] in kala and manthana is commonly unarticulated, therefore, kalamanthana is pronounced kalmantan or klemantan or quallamontan, and eventually became Kalimantan. Meanwhile the Nagarakrtagama text written in $1365 \mathrm{CE}$ indicated that the indigenous people of Sarawak and Sabah called the island as Klemantan.

2 before 1957, Kalimantan Tengah was an integrated part of Kalimantan Selatan under the Government of Kalimantan Selatan

3 late Pleistocene civilization, Austronesian civilization, early Nusantara civilization, Classic (Hindu-Buddhist) civilization, Islamic civilization, Colonial cultural influence, and other specific research interests such as ethnoarchaeology, urban planning, underwater archaeology and archaeologial resource management 


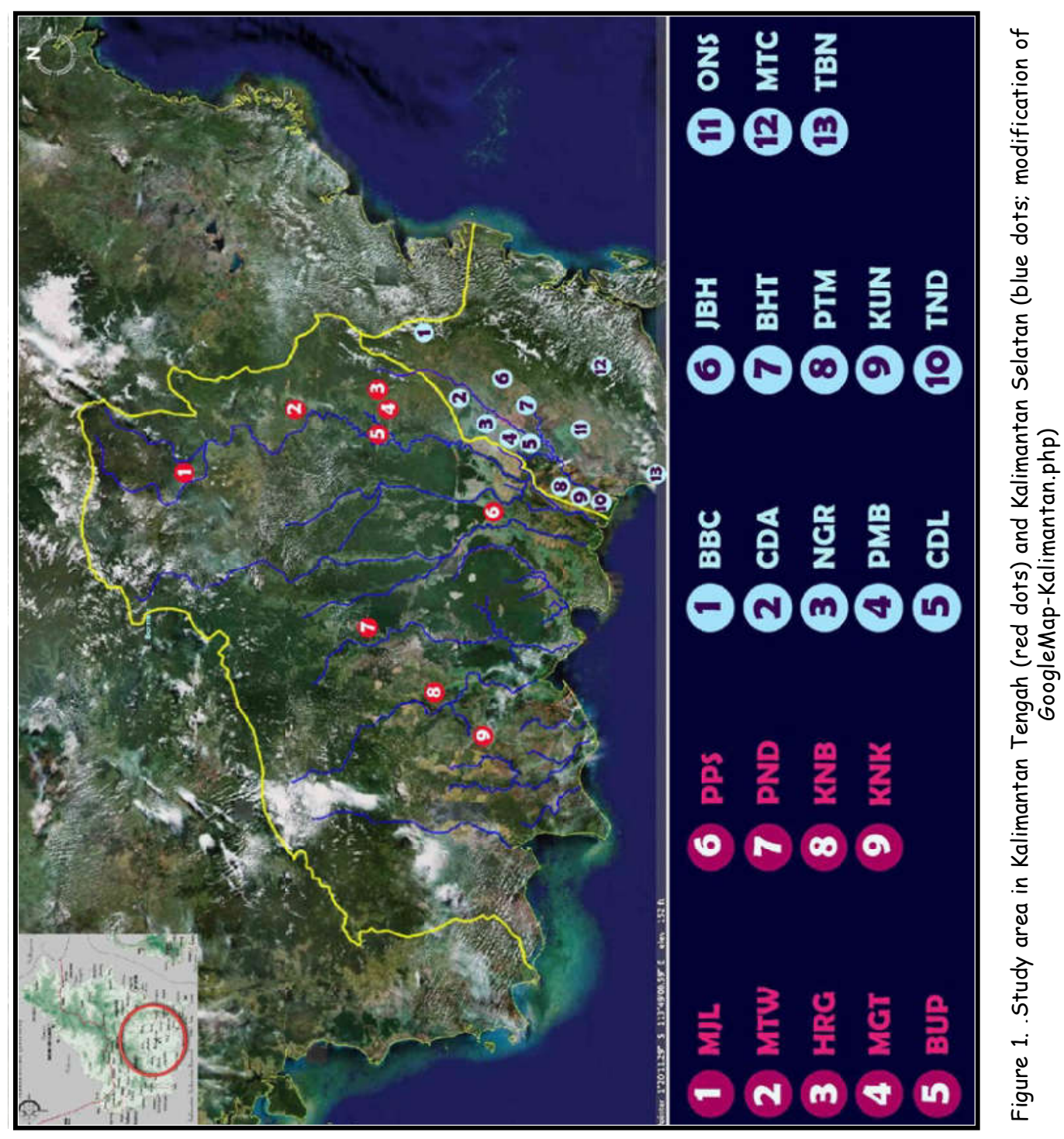


thereafter, the cultural phenomenon will be described with respect to the topography and distinct quality of culture in each region to understand the variability of cultural process that had occurred in Kalimantan Tengah and Kalimantan Selatan in the past.

\section{B. The Archaeology of Kalimantan Tengah}

Kalimantan Tengah is the second largest province in Kalimantan with the highland of the Schwäner-Müller Mountain stretching on the northern region, while most areas in the middle to the south is covered with vast swampy basin formed by nine major rivers ${ }^{4}$ flowing in parallel from the north and empties into the Java Sea in the south. Based on archaeological researches carried out in Kalimantan Tengah, important discoveries on the northern region were found in Muara Joloi I (one) and Muarateweh. Both sites lie at the southern foot $^{5}$ of the Schwäner-Müller Mountain in the northern Barito Basin; they are described as follows:

\section{Muara Joloi 1 (MLJ)}

Presently, Muara Joloi I is the northernmost site found in Kalimantan Tengah. Muara Joloi I is an open site which lies in the east catchment of the Barito River to the north of Purukcahu. The name 'Muara Joloi l' was given by the Bakumpay people who established the village in mid $19^{\text {th }}$ Century (Budhi 2005; Hindarto pers.comm 2010), which forms a linear pattern along the Barito River. Archaeo- logical remains which was found on the riverbank and cultivation comprising: 1) stone adze (andesite and basalt) showing unfinished surface; 2) bark cloth beaters (andesite) showing engraved patterns; 3) red-slipped, plain and decorated potsherd with burnished or unburnished surface indicating the use of sand as temper; and 4) microlith. Oktrivia (pers.comm 2010) assumed the stone tool traditions occurred in the upperstream of Barito is similar to that of the Kapuas (Kalimantan Barat).

\section{Muarateweh (MTW)}

Approximately 3 kilometer downstream of the Barito River, is the wreck site of the Onrust; the Dutch patrol boat (steam boat; Koestoro pers.comm 2010) commanded by Commander Van der Velde, which was attacked and drowned by Antasari, Temenggung Surapati and their men during the Battle of Banjar on 26 December 1859 (id.wikipedia.org/wiki/Perang_Barito). The 2006 underwater survey had mapped the exact location of one part of the ship, yet it was not possible to determine whether it was the bow or stern of the ship due to excessive underwater sedimentation (Koestoro pers.comm 2010).

Notable discoveries on the middle and southern region were found in Bipakali, Ugangsayu and Patas 1, Haringen, Magantis, Pulang Pisau, Pendahara, Keleka Nahan Biru and Keleka Natay Kunang. The nine sites lie in the southern and southwestern Barito Basin; they are described as follows:

\footnotetext{
Barito, Kapuas kecil, Kahayan, Sebangau, Katingan, Sampit, Pambuang, Arut and Lamandau at the altitude of 100-200 meter above sea level
} 


\section{Bipakali, Ugangsayu, and Patas 1 (BUP)}

Bipakali, Ugangsayu and Patas 1 lie on the lowland of the eastern Barito Basin and inhabited by the Lawangan people. Until today, the Lawangan people still practice mortuary ritual comprising two forms of mortuary treatment; primary mortuary treatment is practiced by burying the deceased in an interment, whereas secondary treatment is exercise by exhuming the remains of the deceased, cleansing by way of consecrating without cremation and storing disarticulated skeleton into jars and small wooden casket. Wasita (2006, 12-14; Fajari pers.comm 2010) assume the materialization of eschatology of the Lawangan people is similar to that of the prehistoric people which is indicated by four characteristics i.e. two forms of mortuary treatment, the use of container in secondary burial, grave good furnishing and storage location in mountain fissure; in terms of the Lawangan people the container is placed on elevated platform or crowning a pole.

\section{Haringen (HRG)}

Haringen lies in the lowland of the northeastern Barito Basin. Maan Wada and Ariun (pers.comm 2000) claims that prior to the fall of Nansarunai Kingdom in the $14^{\text {th }}$ Century, the people of Haringen had established 19 villages, and Haringen is the $22^{\text {nd }}$. Presently, the village is inhabited by the Maanyan people who uphold the Paju Sepuluh values. The investigated site of Haringen lies to the southeast of Sirau River ${ }^{6}$ surrounded by cultivation and rubber plantation. Archaeological remains found within the compound comprise of Chinese, Annamese and European ceramic ${ }^{7}$, potsherd (cooking pot), ironslag and debitage (Wasita 2002, 16-19; Kusmartono 2008, 51). Presently, Haringen is acknowledged as an old abandon Maanyan settlement site dated back from the transitional period of Hindu civilization into Islam (or Colonial).

\section{Magantis (MGT)}

Magantis lies to the east of Sirau River on the southernmost region of Magantis village surrounded by cultivation. Presently, the inhabitant of Magantis is the Bakumpay people. Archaeological findings in Magantis comprise of potsherds (plain and decorated), fragment of wooden artefact, fragment of metal bowl, glass beads, baked clay bricks, Chinese ceramic (plates), charcoal that associate with cremation, and a concentration of jar burial which was found by the villagers (Wasita 2002, 22-29). Wasita $(2002,31)$ assumed the unearthed findings have close association with burial activity in Magantis in the past. He assumed also that Chinese ceramic plates were used as lid to cover the jar opening, and spatial setting of the burial jars does not indicate specific pattern or randomly buried.

\section{Pulang Pisau (PPS)}

Pulang Pisau is located in the upper stream of Palawi River surrounded by swamp scrubs, rattan, rambutan (Nephelium) and mango (Nitihaminoto et.al.1998/1999, 2-3). The archaeological remains unearthed were 1) potsherd (local and imported $\left.{ }^{8}\right)$ i.e. cooking

$6 \quad$ tributary of the Barito

7 Yuan Dynasty ( $13^{\text {th }}-14 t^{\text {th }}$ Century), Ming Dynasty (early $15^{\text {th }}-16^{\text {th }}$ Century), Qing Dynasty (17th-19th Century), Annamese (14th Century) and Chinese-made-European ceramic (18th-19th Century)

$8 \quad$ Trowulan type (Nitihaminoto 1998/1999:19) 
pot, lid and lid handle, bowl with footring, decorated carination, plate, jar, water pitcher (kendi); 2) terracotta fragments (roof ridge); 3) ceramics from China, Thailand and Annam; 4) glass beads; 5) grinding stone; 6 ) fragments of metal artefact; 7) ocher; and 8) resin. Based on the ceramics, Nitihaminoto $(1998 / 1999$, 36-38) assumes Pulang Pisau as a $15^{\text {th }}-16^{\text {th }}$ Century settlement site, which forms a linear pattern along the Danau Layang River and inhabited by fishermen and merchants.

\section{Pendahara (PND)}

Pendahara lies in the lowland of the southwestern Barito Basin, exactly to east of Katingan River (Sulistyanto 2004, 20) and presently, inhabited by the Ngaju people. Similar to the Lawangan people in Bipakali, Ugangsayu and Patas 1, the Ngaju in Pendahara recognize two forms of mortuary treatment, primary and secondary, and cleansing by way of consecrating without cremation. However, instead of storing disarticulated skeleton into jars and small wooden casket on elevated platform, the Pendahara Ngaju placed the remains of the deceased in small wooden casket which then is stacked in a wooden house-like vault with the remains of other individuals. Therefore, it can be inferred that generally, the materialization of eschatology of the Pendahara people is similar to that of the Lawangan people.

\section{Keleka Nahan Biru and Keleka Natay Kunang (KNK)}

Keleka Nahan Biru is an old abandon village that lies on top of a small hill on the west bank of the Cempaga River surrounded by swamp and forest of ulin (Bornean ironwood Eusideroxylon zwageri; MacKinnon 1997, 130), rattan and rubber. The investigated area is overgrown with thick immature prickly rattan. One sandong ${ }^{9}$ structure and the remains of another were found aligned north to south parallel to the course of the Cempaga River. Both sandong were established after the Dutch began to steadily occupy Kalimantan in the early 1800s. The sandong are accompanied by sapundu gapit ${ }^{10}$, sapundu kurban ${ }^{11}$, and sanggaaran ${ }^{12}$.

Keleka Natay Kunang lies near the old pier of Natay Kunang close to the junction of the Raku and Rinjau Rivers in the southern region of the Barito Basin. The environment of the surveyed region is secondary forest, which is cleared to cultivate rain-fed rice and tubers in rotation. Among these crops are also grown long-term timber species such as bamboo, jackfruit, ulin, rattan, and rubber trees. Two clusters of old sandong, Sandong Marotan and Sandong Rami, were separated by a relatively small river, the Raku, which flows northeast and joins the Rinjau and eventually the Seranau River. The sandong and its paraphernalia are assumed as the continued materialization of the Ngaju eschatology which

wooden house-like vault on poles

paraphernalia in the form of wooden post crowned by human figure

wooden post crowned by human figure used for tethering sacrificial animal

decorated post symbolising the Tree of Life 
associates with the mortuary tradition of the Austronesian-language-speaking people (Kusmartono 2005, 28).

\section{The Archaeology of Kalimantan Selatan}

Among the four provinces, Kalimantan Selatan is the smallest, but it is also the most populated region ${ }^{13}$. The Meratus Mountain stretches from north to south splitting the province into two different topographies, which are the highland in the east region and the swampy basin formed by the Barito River in the west. Important archaeological discoveries in the highland are the Bukit Batu Buli and Mentewe Cave complex. The two complexes are described as follows:

\section{Bukit Batubuli Complex (BBC)}

There are more than 41 caves found at the foot of Bukit Batu Buli on the northernmost region of Meratus Mountain. Among the caves, Gua Babi and Gua Tengkorak present significant archaeological data. Each cave is located on different sides of the hill; Gua Babi is on the east and Gua Tengkorak on its west. The archaeological remains found in Gua Babi comprise of 1) stone tools i.e. scraper (basalt and chert), borer (basalt and chert), points (basalt, chert, limestone and fossilized bone), tanged-point, which is similar to that of Timor (Glover 1973 in Widianto et.al. 1997, 18), flakes and blades (basalt and chert), core (silicified rock), hammerstone (basalt), pestle (basalt), anvil (basalt), chopper (basaltic andesite), chopping tool (basaltic andesite), hand axe (basaltic andesite) and debitage; 2) bone tools i.e. points (macro and micro-fauna) and double points, spatula (femur of Macaca sp.) and ornament (pendant); 3) potsherd (bowl and cooking pot); 4) mollusk ${ }^{14}$ and animal remains ${ }^{15}$ (alimentation and ornaments); 5) shell-bed; and 6) human remnants (Widianto et.al. 1997, 17-29; 2003, 30-43). On the other hand, archaeological remains found in Gua Tengkorak were 1) stone tools i.e. scraper (basalt and chert), flakes and blades (basalt and chert), core (silicified rock), chopping tool (basaltic andesite), and debitage; 2) mollusk and animal remains; 6) human remains (Widianto et.al. 2003, 23-24).

Widianto (et.al. 2003, 46; 48; 60) claims the human remains in Gua Tengkorak was associated with primary burial with flexed position, which was identified as an Austromelanesid individual, who had practiced lithic culture in the region of Bukit Batu Buli. Therefore, he assumed the chronology of both caves is approximately 8.000 BP. Further, he asserts the inhabitant of Gua Babi had obtained daily nutrition, especially Gastropod, from the natural resources surround the cave; however, they had walked as far as 1.5 kilometer to Uya River in search of raw material for stone tool making. In regard to cave signification, Gua Babi was recognized as dwelling, whereas Gua Tengkorak a burial site.

\footnotetext{
$13 \quad 36,985$ square kilometer; 88 inhabitants per $\mathrm{km}^{2}$

14 Cycloporidae, Planorbidae, Trochomorphidae, Achadae, Thiaridae, Lymnaeidae, Ampulariidae, Pupinidae, Cypreae and Unionidae

15 Ordo Artidactyla, Carnivora, Chiroptera, Rodentia and Primata
} 


\section{Mantewe Cave Complex (MTC)}

Mentewe cave complex comprise of a number of caves which scattered on the southernmost region of Meratus Mountain. Intensive investigation was carried out in Gua Sugung, Gua Payung (Kusmartono 2006) and Liang Bangkai (Sugiyanto 2008 and 2010). The archaeological remains unearthed in the three sites are relatively similar comprising mollusk and faunal remains (alimentation), potsherd (plain and decorated), stone tools (flakes and blade), core and debitage. Based on the artefacts, it is assumed that Gua Sugung and Gua Payung were inhabited by humans employing Mesolithic technology, whereas Liang Bangkai indicates the use of meso-neolithic technology (Sugiyanto pers.comm 2010; Herwanto pers.comm 2010).

Major archaeological discoveries in the flat coastal lowland and wetland are Tabanio, Patih Muhur, Kuin, Tendean, Oranje Nassau, Candi Laras and Pematang Bata, Banua Halat, Nagara, Jambu Hilir and Candi Agung. The twelve sites are described as follows:

\section{Tabanio (TBN)}

Tabanio ${ }^{16}$ lies to the west of Tabanio River on the westcoast of Silat Peninsula. A structure of the foundation of Fort Tabanio was unearthed in association with artefacts such as baked clay bricks, shingles and tiles of terracotta, potsherd, ceramic (Chinese, European and Singkawang), fragments of bottles and glasses, metal and marble. The structure is assumed to be approximately 6.700 square meters in width with bastion erected in every corner of the structure. A small canal was made surrounding the site which is assumed to prevent enemy from easily entering the fortress.

The Dutch archive describes the establishment of Fort Tabanio in 1789, and became the 'silent' witness of the Banjar Battle in 1859. But, there has not been any information on the depiction of its architecture and layout. The unearthed structure itself did not provide sufficient data to construe the architecture above it. Nevertheless, Sonny (et.al. 1995, 9) asserts the technology for building the fortress' foundation had used a combination of raw materials of lateritic rocks, coral, baked clay bricks, ulin poles and sand.

\section{Patih Muhur (PTM)}

Patih Muhur lies on the swampy lowland hemmed in by the Barito, Patih Muhur and Handil River (Wasita 2007, 17). The excavation unearthed two structures of a large number of ulin poles. One structure was systematically arranged in interval consisting over 100 huge poles ${ }^{17}$ that were implanted in the earth as deep as 4-6 meters. Based on the dimension, volume and weight of the ulin, the soil bearing capacity and the quantity of poles, Wasita $(20007,42)$ assumed that a massive architecture was constructed over the structure. The other structure was systematically arranged in a row consisting smaller poles ${ }^{18}$ forming an underground retaining wall encircling the first structure. The retaining wall was erected to prevent erosion caused by the current of Barito River. Wasita also reports the chronology of Patih Muhur is

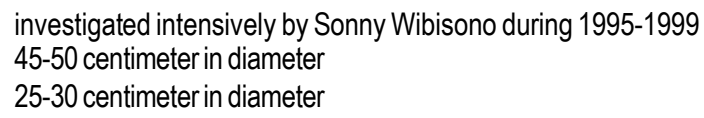


$1310 \mathrm{CE}$, which suggest its establishment was 216 years earlier to the founding of the Sultanate of Banjar.

\section{Kuin (KUN)}

Kuin lies on the northeastern Kuin Basin, approximately 1.5 kilometers to the east of Barito River. Presently, the archaeological landmarks of Kuin are the old mosque ${ }^{19}$ of the first Sultan of Banjar, Suriansyah, and his family cemetery ${ }^{20}$. However, interestingly, the Sultan's family cemetery was establish over a large structure of large bricks which is assumed as the remains of a worshipping platform dated back from the Classic period (Hindu-Buddhist period). The 2004-2006 research which aimed to find the location of Sultan's palace obtained toponymy such as jagabaya, pangeran, sugaling, pinarangbaya and tembokbata (Gunadi 2004, 6).

\section{Tendean (TND)}

Tendean is the name of a street that stretches along the eastern bank of Martapura River in Banjarmasin. Prior to excavation, the ships' rudder was already seen above the mudcovered bank (Widianto et.al.1997, 2). Six types of artefact were found during the 19971998 research i.e. components of the ship, iron and brass artefact (non-ship-component), VOC coins, glass fragments (bottle, glass, bowl and prismatic object), German stoneware bottle, ceramic (Chinese, Vietnam, Thailand, Dutch, British, other European country and local) and potsherd (basin, cooking pot, jar, shingles, stove, pontil). The ship material and technology is typical $20^{\text {th }}$ Century and locally made in Indonesia (Koestoro pers.comm 1997), although it was used by the Dutch for patrolling the waters surround Fort Tatas, the Dutch resident, Kampung Kraton, Chinatown and docks as the centre of political and economic activity.

\section{Oranje Nassau (ONS)}

Fort Oranje Nassau lies at the western foot of the Meratus Mountain to the west of Riam Kiwa River. The archive of Governor General Rochussen states that the fortress was established by the Dutch in 1849 to protect their coal mine (Sugiyanto 2007, 26). The research discovered three structures of baked clay bricks which associate with the mining activity, office for administration and particular defense structure.

\section{Candi Laras (CDL) and Pematang Bata (PMB)}

Candi Laras lies on a wetland grown with sago and galam (Melaleuca Cajuputi; MacKinon et.al. 1996, 130) hemmed in by Nagara, Tapin and Amas River. During 19701987 , the local office carried out a survey and found fragment of a stone inscription, gold jewelry, VOC and Chinese coins, precious stones and a bronze Buddhist figure. Presently, these findings are housed in the Lambung Mangkurat Museum in Banjarbaru. During 1997-1998, researches carried out by the Centre for Archaeology, Banjarmasin, in Candi Laras unearthed two structure of ulin poles. The result of radiocarbon dating on ulin in Candi Laras is 1330 CE (Sulistyanto 2000, 36).

On the other hand, Pematang Bata, known to the local as 'Tjandi', is located to the interior of the wetland, which is to the south of Bata River. Besides baked clay bricks, potsherd, ceramic, chunks of quartz and

\footnotetext{
19 erected in $1526 \mathrm{CE}$

20 Suriansyah died in 1550 CE
} 
limestone and fossilized wood, significant amount of charcoal was found (Rangkuti et.al.1999, 15). Based on the charcoal, the chronology of Pematang Bata is $1140 \mathrm{CE}$ (Sulistyanto et.al. 1999, 23).

\section{Banua Halat (BHT)}

Banua Halat is the name of an old mosque which lies to the west of Tapin River. Usman (2000, 26 in Cynthia 2007, 8) claims the mosque had once benefitted by Sultan Muda Abdurrahman as the basis to fight the Dutch in 1840 CE. The mosque was burned down by the Dutch in 1890, but immediately rebuilt by the people of Banua Halat. And, in 1935 , the wooden floor was replaced by ceramic tiles. Cynthia $(2007,30)$ informs the existence of an oral tradition relating to the establishment of the mosque of Banua Halat by Datu Ujung or Palui Anum, a Bukit people who once was an adherent of Kaharingan before converting to Islam, yet the identity and date of establishment remains in question. $A$ radiocarbon dating has been carried out with sample taken from an ulin (Eusideroxylon zwageri) bar, which was assumed as the remains of the mosque prior to 1890 fire; however, the result ${ }^{21}$ does not comply with the characteristic of the mosque (Gunadi 2006, $6)$.

\section{Nagara (NGR)}

Nagara lies on the eastern Barito Basin, which is to the east of the Nagara River. This village is known as the main manufacturer of pottery and metalworking for centuries. The finest clay resource for pottery making is provided abundantly in Nagara and pottery production is made for daily use comprising small stove, cooking pot and pot lid, basin, mortar, water vessel (kendi), large jar, incense burner, molding pot, vase, piggy-bank and toys. On the other hand, metalworking is dominated by goldsmithing and ironsmithing which produce gold plated jewelry, iron propeller, irons hook and cookie cast (Hartatik 2006, 215).

Craftsmanship has been passed on from one generation to the other and it has been also the primary occupation in Nagara (Sulistyanto et.al. 1999/2000, 20). Interestingly, professionalism ${ }^{22}$ in pottery and metalworking is highly considered rather than labor differentiation based on gender. In regard to marketing, the distribution of Nagara pottery and metalwork is by means of Pasar Apung (floating market) in Kuin and Lok Baintan, which then is circulated further by smaller merchants.

\section{Jambu Hilir (JBH)}

Jambu Hilir lies on the former Sungai Rangas-Tatau riverine plain, which was a tributary of the Amandit (Nasruddin 1996/7 in Anggraeni 2008, 120). The 2007 excavation yielded potsherd (decorated and red-slipped), iron fragments (blade, ironslag), baked clay beads and pellet, charcoal, red ochre, and unworked siliceous pebbles. Anggraeni (2008, 125) reports the chronology of Jambu Hilir is $970 \mathrm{BCE}$, which is considered the oldest date for Metal Age site in Indonesia. She also claims that Jambu Hilir was occupied until the Dutch period.
4720-4370 BCE

searching raw material, making process and marketing 


\section{Candi Agung (CDA)}

Candi Agung lies in the lowland of the eastern Barito Basin approximately 5 meters to the northeast of Malang River, a tributary of the Nagara. Presently, the site is located in the middle of the densely populated town of Amuntai. The archaeological discovery comprise of two interesting characteristics. First, which associate directly with the name of the site is the brick structures dated back from the $728 \mathrm{CE}$, and second, a 20-centimeterthick layer of solid charcoal associated with potsherd ${ }^{23}$ dated back from 350 BCE. Such findings denote the repeated land use of the site for settlement and later for ceremonial purpose (Kusmartono et.el. 1998, 23).

\section{Cultural Development}

The archaeological information above provide a general description on the distinctive quality of what had occurred in the past, which are: 1) the continuous prehistoric tradition practiced by the Lawangan, Maanyan and Ngaju people in Kalimantan Tengah, especially involving mortuary treatment, combined with more recent pattern affected by the Hindu and Islamic culture; and on the other hand 2) the strong Islamic and Colonial influence signified by Kuin and Banua Halat mosques, and the establishment of two fortresses of Tabanio and Orangje Nassau to control the political and economic policy and activity in the Sultanate of Banjar in Kalimantan Selatan. Nevertheless, there are two main consecutive causal factors to explain the distinct quality of cultural development in each region i.e. natural environment which affected the development of civilization.

Geographically, Kalimantan Tengah and Kalimantan Selatan have similar physiographical condition, identified as southem Kalimantan, yet administratively, each region present dissimilar topographical division. Kalimantan Selatan which is 36.985 square kilometer in width is divided into two landscapes by the Nagara River and forms the swampy lowland in the west and highland to its east. On the contrary, the width of Kalimantan Tengah is $427.15 \%$ larger than that of Kalimantan Selatan; the region is sliced by nine enormous rivers creating vast swampy lowland and leaving the upland secluded in the north. Until the turn of the century, both regions had been occupied by the Austromelanesid and Austronesian-languagespeaking people, yet there has been no record indicating both group had met in a certain point of time and space. Considering the natural environment then, one may imagine the difficulty of both groups to survive, let alone make social interaction. Nevertheless, it is reasonable to assume that they had chosen the highland to survive rather than the swampy lowland which was occupied by devious water creature, especially the estuary crocodiles ${ }^{24}$.

The oldest date relating to the existence of early civilization in southern Kalimantan is represented by Gua Tengkorak ( $8,000 \mathrm{BP})$ in Tabalong. And, later evidences of prehistoric civilization in Kalimantan were found in Nanga Balang (3,000 BP) in Kapuas Hulu, Mentewe (ca. 3,000 BP) in Tanah Bumbu, Jambu Hilir (2,920 BP) in Hulu Sungai Selatan, Liang Jon

23 approximately 75 meters to the southeast of the structure and 140 centimeters below ground

24. 6-7 meters in length 
(ca. 2,500 BP) in Kutai Timur and Candi Agung (2,300 BP) in Hulu Sungai Utara. Between the groups, the Austronesian-language-speaking people was considered to be more sophisticated than the Austromelanesid, since they have the knowledge to practice agriculture, domesticate animals and navigate. The Austronesian's skill to navigate ${ }^{25}$ had outmoded the Austromelanesid and enabled them to travel frequently and explore new places, either inter-island or intra-island.

The civilization in Kalimantan developed progressively since the world (India and China; Wolters 1967, 31) began to take interest in Kalimantan's rich natural resources of gold, camphor, resin, aromatic products and precious stones (Munoz 2008, 76-84). The desire to exploit Kalimantan's natural resources was encouraged by the tale of 'Suvarnabhûmi' which literally means the land of gold, political change in Mediterranean and Central Asia, development of vessel technology and the expansion of Buddhism (Wheatley 1983, 263-272). As a result old Hindu kingdoms began to flourish such as M ûlavarmman (500 CE) in the eastern Kalimantan and Pu-ni (ca. $400 \mathrm{CE}$ ) in northern Kalimantan ${ }^{26}$ (Slametmulyana 1976, 146; Kusmartono 2000, 15). Strangely, there were no further historical records in regard to the development of both kingdoms.
300 years later, a Buddhist 'mantra', Batu Pait, was engraved on a monolith erected in the Kapuas Basin in western Kalimantan, possibly denoting that a group of priests were conduting ritual activity. Another one was engraved on a smaller stone plate and brought to southern Kalimantan ${ }^{27}$. Later in $1365 \mathrm{CE}$, the Nagarakretagama text, written by Prapanca, mentioned the existence of vassal states in Kalimantan comprising KapuasKatingan, Sampit, Kota Lingga, Kota Waringin, Sambas, Lawai, Kadandangan, Landa Samadang, Tirem, Sedu, Barune (ng), Kalka, Saludung, Solot, Pasir, Barito, Sawaku, Tabalung, Tanjung Kutei and Malano (Slametmulyana 1979, 144-146 and 280). At the same time, two oral traditions ${ }^{28}$ mention the existence of Hindu kingdoms of Kutai Kartanegara, Martapura and Pantun in eastern Kalimantan and Nagara Dipa and Nagara Daha in southern Kalimantan.

161 years later, the Sultanate of Banjar was founded under the reign of Sultan Suriansyah. The Sultan's sovereignty encompasses smaller kingdoms in southern ${ }^{29}$ and eastern ${ }^{30}$ Kalimantan. However, Islamic civilization had made an impact in Kalimantan prior to the establishment of the sultanate, which is evident by the 'keramat tujuh' indicating seven typical Majapahit 'Tralaya' tombstones written with Old Javanese letter bearing the date of the deceased. Simultaneously, the Dutch began also to exercise its political and economic policy by

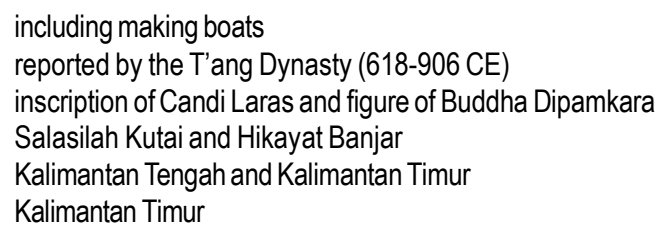


building fortresses and Christian missionaries began their mission by traveling to the interior of western, central and eastern Kalimantan, whereas Islamic civilization flourish significantly in the southeastern region.

The civilization in Kalimantan seems to be developing irregularly, appearing and disappearing from time to time. I assume the main reason for such condition to occur is caused by how people in the past initially perceived Kalimantan whether mainly as a resource which can be exploited indefinitely or a place to interact, survive and build civilization.

\section{E. Conclusion}

The archaeology between Kalimantan Tengah and Kalimantan Selatan shows significant variability. The material cultures in Kalimantan Tengah tend to present evidences of continuous mixed tradition of prehistoric, Indic and Islamic culture of mortuary management. On the other hand, the archaeological evidences discovered in Kalimantan Selatan indicate definite existence of prehistoric civilization from approximately 6000 until 400 BCE, the influence of Indic culture between 800 and $1400 \mathrm{CE}$, and the supremacy of Islamic and Colonial influence during 1500-1900 CE. Nevertheless, the ecological differences in the southern region, which administratively is encompassed within the provinces of Kalimantan Tengah and Kalimantan Selatan, had influenced the level of human requirement to perform social interaction in order to survive. The achievement of such interaction depended on the standpoint of cultural perception of every group of people. Furthermore, human capability to interact had affected the growth of demography in a certain region and specialization in economic and social sector. The highest level of social interaction in Kalimantan Tengah and Kalimantan Selatan is the existence of Sultanate Banjar's sovereignty in both regions. Conclusively, the characteristic of cultural development in the southern region of Kalimantan depends on humans' perception toward their natural environment either upperstream-downstream, fertile-infertile, marshland-desert, highlandlowland, which then developed into cultural constructed environment as, either sacred or profane landscape, and benefitted as their interaction cauldron. 


\section{Referensi}

Anggraeni and Sunarningsih. 2008. The Prehistoric settlement at Jambu Hilir, South Kalimantan Province, Indonesia, Ejournal Bulletin of the Indo-Pacific Prehistory Association Vol. 28, 120-126.

Airun, Maanyan. 2000. (Personal communication, 15 May 2000).

Budhi, Setia. 2005. Melacak jejak suku Dayak Bakumpai. Kompas, 9 Juli 2005. http://www.kompas.com dan http://www.jurnalisme.org/ Forums/viewtopic/t=70.html

Cynthia, Fakhriah. 2007. Karakterisktik masjid keramat Banua Halat, Kabupaten Tapin, Kalimantan Selatan. Undergraduate thesis. Yogyakarta: Universitas Gadjah Mada. unpublished.

Fajari, Nia Marniati Etie. 2010. (Personal communication, 1 August 2010).

Glover, I. G. 1973. Late stone age traditions in Southeast asia. First International Conference of Southeast Asian Archaeology. London: Gerald Duckworth \& Co. Ltd.

Gunadi. 2004. Melacak sisa-sisa Kerajaan Banjar di kawasan Kuin dan Kayutangi, Kalimantan Selatan. Laporan Penelitian Arkeologi. Banjarbaru: Balai Arkeologi Banjarmasin. unpublished. 2006a. Kajian arkeologi situs masjid keramat Banua Halat. Laporan Penelitian Arkeologi. Banjarbaru: Balai Arkeologi Banjarmasin in collaboration with Dinas Kebudayaan dan Pariwisata Kabupaten Tapin. unpublished.

. 2006b. Survei Kapal Onrust di Hulu Sungai Barito. Laporan Penelitian Arkeologi. Banjarbaru: Balai Arkeologi Banjarmasin in collaboration with Dinas Pariwisata, Kebudayaan, Seni Budaya, Informasi dan Komunikasi Kabupaten Barito Utara. unpublished.

Herwanto, Eko. 2010. (Personal communication, 9 August 2010).

Hindarto, Imam. 2010. (Personal communication, 5 August 2010).

http://id.wikipedia.org/wiki/Kalimantan http://id.wikipedia.org/wiki/Perang_Barito)

Koestoro, Lucas Partanda. 2010. (Personal communication, 10 August 2010).

Kusmartono, Vida Pervaya Rusianti and Harry Widianto. 1998. Ekskavasi situs Candi Agung, Kabupaten Hulu Sungai Utara. Berita Penelitian Arkeologi no. 02. Banjarmasin: Balai Arkeologi Banjarmasin. 
Kusmartono, Vida Pervaya Rusianti. 2000. Posisi Candi Laras dan Candi Agung pada kerangka sejarah budaya Masa Klasik di Kalimantan Selatan. Naditira Widya no. 4. Banjarbaru: Balai Arkeologi Banjarmasin. pg. 1117.

2005. The sandong of the Ngaju: mortuary variability in southern Kalimantan. Thesis. Canberra: the Australian National University. unpublished. 2006. Penelitian hunian gua prasejarah di Kabupaten Tanah Bumbu. Laporan Penelitian Arkeologi. Banjarbaru: Balai Arkeologi Banjarmasin. unpublished. . 2008. Permukiman kuna dan sistem penguburan Haringen. Berita Penelitian Arkeologi vol. 2 no. 1. Banjarbaru: Balai Arkeologi Banjarmasin. pg. 4368.

MacKinnon, Kathy, Gusti Hatta, Hakimah Halim and Arthur Mangalik. 1997. The ecology of Kalimantan. Indonesian Borneo. The Ecology of Indonesia Series volume III. Singapore: Oxford University Press.

Muchammad, Bani Noor and Ira Mentayani. 2007. Anatomi Rumah Bubungan Tinggi. Banjarmasin: Pustaka Banua.

Muljana, Slamet. 2006. Sriwijaya. Yogyakarta: LKiS.

Munoz, Paul Michel. 2008. Early Kingdoms of the Indonesian Archipelago and
Malay Peninsula. Singapore: Didier Millet Pte Ltd.

Nasruddin et. al. 1996/1997. Ekskavasi situs Jambu Hilir di Kabupaten Hulu Sungai Selatan. Laporan Penelitian Arkeologi. Banjarbaru: Balai Arkeologi Banjarmasin. unpublished.

Oktrivia, Ulce. 2010. Survei eksplorasi guagua hunian di Kabupaten Murungraya. Laporan Penelitian Arkeologi. Banjarbaru: Balai Arkeologi Banjarmasin. unpublished.

Oktrivia, Ulce. 2010. (Personal communication, 5 August 2010)

Rangkuti, Nurhadi and Vida P. R. Kusmartono. 1999. Peneltian situs Candi Laras tahap IV. Laporan Penelitian Arkeologi. Banjarbaru: Balai Arkeologi Banjarmasin. unpublished.

Rusan, Ahim S. et. al. 2005. Sejarah Kalimatan Tengah. Palangkaraya: Lembaga Penelitian Universitas Palangkaraya dan Pemerintah Provinsi Kalimantan Tengah.

Mulyana, Slamet .1976. Nagarakretagama dan tafsir sejarahnya. Jakarta: Bhratara Karya Aksara.

Sugiyanto, Bambang. 2007. Situs Benteng Oranje Nassau. Berita Penelitian Arkeologi vol. 1 no. 1. Banjarbaru: Balai Arkeologi Banjarmasin. pg. 26-39. . 2008. Ekskavasi Gua-gua Mentewe tahap I. Laporan Penelitian Arkeologi. Banjarbaru: Balai Arkeologi Banjarmasin. unpublished. 
. 2010. Ekskavasi Gua-gua Mentewe tahap II. Laporan Penelitian Arkeologi. Banjarbaru: Balai Arkeologi Banjarmasin. unpublished. 2010.

(Personal communication, 9 August 2010)

Sulistyanto, Bambang and Siswanto. 1999. Pertanggalan radiokarbon situs Pematang Bata. Laporan Penelitian Arkeologi. Banjarbaru: Balai Arkeologi Banjarmasin. unpublished.

Sulistyanto, Bambang. 1999/2000. Penelitian etnoarkeologi tradisi pembuatan gerabah Nagara, Kabupaten Hulu Sungai Selatan. Berita Penelitian Arkeologi no. 5. Banjarmasin: Balai Arkeologi Banjarmassin.

2000. Umur Candi Laras dalam pangung sejarah Indonesia Kuna. Berita Penelitian Arkeologi no. 07. Banjarbaru: Balai Arkeologi Banjarmasin. - 2004. Upacara tiwah masyarakat Dayak Ngaju di Pendahara. Berita Penelitian Arkeologi no. 13. Banjarbaru: Balai Arkeologi Banjarmasin.

Susanto, Nugroho Nur. 2010. (Personal communication, 17 August 2010)

Treacher, W. H. 1889. British Borneo. Malaysian Branch of the Royal Asiatic Society (MBRAS) journal.

Wada, Maan. 2000. (Personal communication, 15 May 2000)
Wasita. 2002. Sistem penguburan dan upacara Marabia pada masyarakat Paju Sepuluh di Kabupaten Barito Selatan. Berita Penelitian Arkeologi no. 10. Banjarbaru: Balai Arkeologi Banjarmasin.

2006. Sistem penguburan umat Kaharingan Dyak Lawangan. Berita Penelitian Arkeologi: Etnoarkeologi Religi Dayak di Kalimantan no. 16 Special edition. Banjarbaru: Balai Arkeologi Banjarmasin. . 2007. Ekskavasi permukiman lahan basah di situs Gambut dan Patih Muhur. Laporan Penelitian Arkeologi. Banjarbaru: Balai Arkeologi Banjarmasin. unpublished.

Wibisono, Sonny Ch., Novida Abbas, Vida P. R. Kusmartono and Harry Widianto. 1995. Ekskavasi situs Benteng Tabanio Tahap I, Kabupaten Tanah Laut. Naditira Widya no. 1. Banjarmasin: Balai Arkeologi Banjarmasin.

Widianto, Harry, Truman Simanjuntak adn Budianto Toha. 1997a. Ekskavasi situs Gua Babi, Kabupaten Tabalong, Provinsi Kalimantan Selatan. Berita Penelitian Arkeologi no. 01. Banjarmasin: Balai Arkeologi Banjarmasin.

Widianto, Harry, Lucas Partanda Koestoro, Bambang Sakti Wiku Atmojo and Vida P. R. Kusmartono. 1997b. 
Cultural Development: the Archaeology of Kalimantan Tengah and Kalimantan Selatan 153-169

Ekskavasi arkeologi di kawasan jalur hijau Jalan Kapten Piere Tendean. Laporan Penelitian Arkeologi. Banjarmasin: Balai Arkeologi Banjarmasin. unpublished.

Widianto, Harry and Retno Handini. 2003. Karakter budaya prasejarah di kawasan Gunung Batu Buli,
Kalimantan Selatan: mekanismehunian gua pasca plestosen. Berita Penelitian Arkeologi no. 12. Banjarbaru: Balai Arkeologi Banjarmasin.

Wolters, O. W. 1967. Early Indonesian Commerce. A study of the origins of Srivijaya. London: Cornell University Press. 